\title{
Aromatase, Estrogen and Male Reproduction: a Review
}

\author{
Emin Kaymak ${ }^{*}$, Ayşegül Burçin Yıldırım² \\ ${ }^{1}$ Yozgat Bozok University, Faculty of Medicine, Department of Histology \& Embryology, \\ Yozgat, Turkey. \\ ${ }^{2}$ Gaziantep Islam, Science and Technology University, Faculty of Medicine, Department of \\ Histology and Embryology, Gaziantep, Turkey.
}

\begin{abstract}
The mammalian testis is both an endocrine and an exocrine gland. In addition to gonadotropins and testosterone, estrogens are found in male gonads. Estrogens regulate male gonadal functions. Estrogens perform their functions together with estrogen receptors. Estrogens participate in functions such as pubertal growth and spermatogenesis in men. The aromatase enzyme, a product of the CYP19 gene, is important in the conversion of androgens to estrogens. Aromatase is present in Leydig cells, pachytene spermatocytes, and round spermatids in the testis. Factors such as TGF $1, T N F-\alpha$, and TH have been shown to have a negative effect on aromatase. P450 aromatase deficiency leads to disorders such as high testosterone, infertility, shrinkage and testicular weight, decreased ejaculation, and sperm motility in men. In cases such as oligospermia that develops due to the increase in serum estrogen levels, it has been observed that the level of testosterone increases by using estrogen inhibitors. In this review, changes in male gonads in aromatase deficiency and factors affecting aromatase are stated. As a result, it has been shown that aromatase expressed in the testis is important for male gonad development and spermatogenesis.
\end{abstract}

Ke ywords: Aromatase(CYP19), Infertility, Estrogen, Testis

\section{Aromatase}

Aromatase enzyme, a member of the cytochrome P450 enzyme super family, is involved in the irreversible conversion of androgens to estrogens in male gonads. It is found in the endoplasmic reticulum of cells. P450 aromatase is a microsomal enzyme complex composed of 2 protein. One of them is cytochrome $\mathrm{P} 450$ aromatase (P450arom), which is a specific microsomal heme glycoprotein, containing heme and steroid binding site, the other is a non-specific microsomal flavoprotein NADPH- cytochrome P450 reductase, which is required for the transfer of electrons from NADPH to any cytochrome $\mathrm{P} 450$. P450 aromatase is found on the long arm of chromosome 15 (15q21.2) in humans. It is the product of a single gene called Cyp19 (1-3). In humans, aromatase is expressed in the testis, ovary, placenta,

* Corresponding author: Emin Kaymak, Medical Faculty of Yozgat Bozok University, Department of Histology \& Embryology, E-mail: e_kaymak@hotmail.com, ORCID ID: 0000-0002-3818-2693. 
adipose tissue, skin and brain (4). Its transcription is regulated by cytokines, gonadotropins, cyclic nucleotides, growth factors and glucocorticoids (5).

\subsection{Localization of aromatase in male germ cells}

The cellular localization of aromatization in the testis in rats varies with age. This situation appears to be especially in Sertoli cells in non-adult animals and Leydig cells in adults (6). At the same time, P450arom Leydig cells in adult rats as well as pachythenic spermatocytes are immunolocalized in round and elongated spermatids and spermatozoa $(2,7)$. In a study, aromatase localization in adult rat testicular cells was examined by protein (RT-PCR), mRNA (Western Blot) and cell culture methods. Aromatase mRNA was detected in spermatogonium, spermatocyte, spermatid, sperm, Leydig and sertoli cells. In RT-PCR analyzes, it was reported that aromatase was found at the protein level in spermatids, sperms and Leydig cells. In cell culture, it has been shown that the enzymatic activation of aromatase occurs in spermatocyte, spermatid, sperm, Leydig and Sertoli cells (7). When the aromatase enzyme is investigated in testicular tissue by immunohistochemistry and RT-PCR analyzes, it is complicated in which cells are found in which density according to species and age. In our study, in which aromatase expression was examined in 15day-old and 60-day-old rats, it was found that expression was only in Leydig cells in 15-day-old rats. In 60-day-old rats, expression was observed not only in Leydig cells, but also in round and elongated spermatids, spermatocytes and spermatozoa. In RT-PCR analyzes, it has been shown that the ratio of Cyp 19 mRNA in rats increased from 15 days to 60 days (8).

\section{Aromatase and Estrogens in male germ cells}

Testosterone and gonadotropins (FSH, LH) are involved in the control of normal testicular development and maintenance of spermatogenesis. It is also well known that estrogens are involved in the regulation of male gonadal functions. Estrogen levels in the male reproductive tract are much higher than in the general bloodstream.(1, 9). Estrogen has a very important role in the regulation of pubertal growth, spermatogenesis and gonadal functions in men. (10). It has been reported that estrogen deficiency is due to an inactive mutation of Cyp 19 in various cases. The role of estrogens in male fertility is partly related to the ratio of androgens to estrogens and therefore it is important to better understand the regulation of Cyp 19 gene transcription (2, 7). Accordingly, when the regulation of the aromatase gene in rats is examined, some factors inhibit the expression of Cyp19 in germ cells while others (TNF, TGF, cAMP) stimulate $(7,11,12)$.

\subsection{Biosynthesis of Estrogens}

The biosynthesis of estrogens consists of different steps from cholesterol to estrogen. Steroidogenesis begins with the entry of cytosolic cholesterol into mitochondria via steroidogenic acute regulatory protein (StAR). Later, different enzymes play a role in the conversion of cholesterol to estradiol, the active estrogen. Aromatase (Cyp 19) catalyzes the last step in this conversion. Androstenedione and testosterone transforms into estrone and estradiol, respectively, under aromatase catalysis (Figure 1) (13-15).

2.2 Estrogen receptors (Era ve Er $\beta$ ) in the male reproductive tract 
Testicular estrogens must interact with estrogen receptors (ER) to perform their role. This interaction should regulate the transcription of specific genes (1).

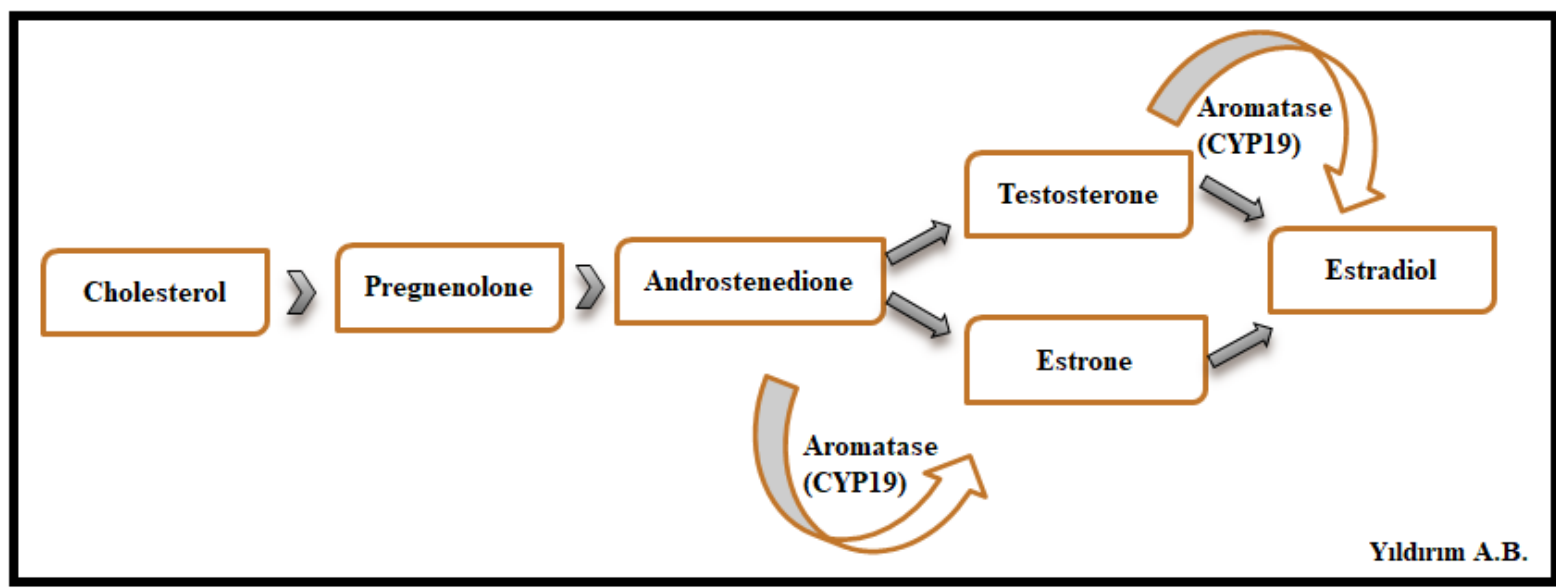

Figure 1: Estradiol biosynthesis and related genes and enzymes.

Estrogen receptors are present in alpha and beta testicular cells. The estrogen concentration exiting the testis is much higher than that in the circulation. Estrogen in certain doses is very important for testicular function. High doses of estradiol or an injection of an estrogen receptor inhibitor are harmful to the testicle and lead to atrophy $(7,16,17)$. In addition, estrogen receptors (ER $\alpha$ and $\beta$ ) are present in the efferent ducts and epididymis. (1820). The presence of abundant estrogen and ER in efferent ducts and epididymis indicates that estrogen has a role in the regulation of these tissues and thus in changing sperm maturation and function.

The absence of ER $\alpha$ causes defects in the development of the efferent duct, which results in dysfunction, particularly in terms of fluid absorption, resulting in fewer sperms entering the epididymis. One consequence of impaired fluid dynamics is fluid accumulation in the testicle, resulting in seminiferous epithelial damage and impaired germ cell development. (21).

\section{Aromatase Deficiency}

Estrogens have important physiological roles in men and women. There are important roles in the development of secondary gender characters in women. In men, it has been said that it may be important in preventing the fusion of epiphyses and bone loss in the first years. Understanding the role of estrogens in mice and humans has been said to have gained importance with the discovery of men and women with mutations in the CYP19A1 (aromatase) and ER (estrogen receptor- $\alpha, \mathrm{ER} \alpha$ ) genes (22-24).

Studies have shown that people with aromatase gene defects have little or no estrogen. While this is an autosomal recessive condition with pseudohermaphroditism in women, it is known to be related to the unfused epiphysis in men $(25,26)$. Mutation in the aromatase gene also causes virilization (hirsutism, acne, cliteromegaly, deep voice) in women (26). Aromatase deficiency is most common during pregnancy. In case of aromatase deficiency in a pregnant mother, virilization is observed in the fetus. There is also testosterone in the maternal circulation 
(22). Estrogen deficiency and resistance in males cause problems such as long stature and delay in skeletal development apart from the effect of pubertal growth. Estrogens have a very critical role in bone development in men. P450 aromatase deficiency in men leads to hypergonadotropism, macroorchidism, fertility problems, and increased serum testosterone concentrations $(27,28)$. In another study, in an adult patient with Klinefelter syndrome, aromatase was stained in Leydig cells and Sertoli cells, and the amount of estrogen in this patient was found to be increased and testosterone level decreased (29). In a different model, AROM ${ }^{+}$, male-sterile mice decreased androgen levels and increased estrogen levels. At the same time, testicular weights decreased (30).

\subsection{Aromatase Inhibitors}

Aromatase inhibitors were originally developed for estrogen receptor positive breast cancer (31). Current data suggest that aromatase inhibitors are possibly effective in treating patients with aromatase excess syndrome or testotoxicosis, partially effective in PeutzJeghers and McCune-Albright syndrome, but possibly ineffective in gynecomastia (32). Aromatase inhibitors inhibit the last stage of estrogen production. It is used in the treatment of breast cancer in postmenopausal women (33). Aromatase inhibitors are divided into two as steroidal and non-steroidal inhibitors (31). Aromatase inhibitors are important in reducing serum estradiol levels. Commonly, 3 aromatase inhibitors are used. These; Anastrozole are letrozole (non-steroidal, exhibiting competitive binding and reversible inhibition) and exemestane (steroidal, inactivation of aromatase by covalent binding) (33).
Steroidal inhibitors (exemestane) bind irreversibly to the substrate-binding site. Unlike steroidal inhibitors, nonsteroidal compounds (imide, aminoglutethimide, and letrozole) bind to the $\mathrm{P} 450$ region of the aromatase complex (34). Aromatase inhibitors have the ability to increase endogenous testosterone production without the associated increase in circulating estrogens (35). They are used in oligospermia and azoospermia (36). As a result of decreasing the estrogen level with the aromatase inhibitor, it was observed that the luteinizing hormone (LH) production increased and thus the level of testosterone in the circulation increased (37).

\subsection{Testicular Function in Models of} Aromatase Deficiency

The mammalian testis has a special and complex structure and is both an endocrine and exocrine organ. It makes its endocrine feature by steroid hormone synthesis. It shows its exocrine feature with the spermatozoon formed (38). Gonadotropins and testosterone are responsible for the stimulation and maintenance of spermatogenesis. Although estrogens are generally found in females, they are also present in male gonads (38). There are estrogens in the male reproductive system. These estrogens are found in the male reproductive system more than the bloodstream (9). In the study conducted these years ago, it was shown that the amount of estrogen at the beginning of the rete testis and epididymis of rats was higher than that in the circulating blood (39).

As a result of the researches, it has been shown that P450 aromatase mRNA expression decreases during rat germ cell maturation and it is abundant in pachytene spermatocytes and elongating spermatids 
rather than round spermatids (2). In humans, biologically active aromatase has been seen in Leydig cells, immature germ cells, and ejaculated spermatozoa $(8,40$, 41). Small testes and severe oligozoospermia have been seen in men with aromatase deficiency (25).

In the study of Aromatase Knockout (ARKO) mice, male gender-specific, and related behaviors were evaluated. It was observed that ARKO mice had impairments in ejaculation, copulation, and all other sexual behaviors. The majority of ARKO mice also had infertility (42). This shows that aromatase-deficient male mice impair sexual behavior. In another study, it was shown that fertility rate, sperm count, round spermatid, and sperm motility were significantly decreased in ARKO male mice compared to normal mice (43). Although very rare in humans, aromatase deficiency has been reported. Several aromatase-deficient men studied were reported to be heterosexual with chronically elevated luteinizing hormone (LH), follicle-stimulating hormone (FSH), and testosterone $(\mathrm{T}) \quad(26,44-46)$. It has been stated that the aromatase found in the brain is required for male sexual activity partially dependent on testosterone, and that brain aromatase is necessary for negative feedback regulation of circulating testosterone from the testis (47).

\section{Molecular Mechanisms of Aromatase Gene Expression in the Testicle}

Estrogen biosynthesis occurs in the endoplasmic reticulum of estrogenproducing cells by $\mathrm{P} 450$ armotase, the product of the CYP19 gene. The CYP19 gene contains nine coding exons (exons II$\mathrm{X})$ and contains a regulatory region upstream of exon II (48). There are promoters that regulate this gene. There is promoter II (PII) in human testis (3). P450 aromatase is capable of metabolizing the three precursors, androstenedione, testosterone, and 16 $\alpha$ hydroxydehydroepiandrosterone sulfate to estrone, estradiol, and estriol, respectively (48, 49). Estrogens are biologically synthesized by aromatase in the rat testis (50). Aromatase mRNA is found in somatic cells, germ cells, spermatids, and spermatozoa in our epididymis in the testis, but it has not been said that there is a relationship between transcript level and enzymatic activity $(1,2)$. While the expression of aromatase is expressed in Sertoli cells during fetal and neonatal periods in rat testes, it is expressed in Leydig, spermatocyte, spermatid, and spermatozoa in adults. $(1,51)$. Aromatase expression decreases with the maturation of germ cells. Pachytene spermatocytes have a higher expression of aromatase than round spermatids and spermatozoan (2). In a study, it has been shown that the expression of aromatase in the testis is associated with age, cell type, and the stage of the seminiferous tubule epithelium (50). In the study conducted in rats, aromatase expression reached its maximum level on the 30th day. While it peaked in Sertoli cells on day 20, this expression decreased at about day 70 (52). When looking at the effect of TGF $\beta 1$ on germ cells obtained from adult rats, it was observed that aromatase was decreased in pachytene spermatocytes and round spermatids. It has been stated that $\operatorname{smad} 2,3$, and 7 play an important role in the TGF $\beta$ pathway in spermatogenesis (11). TNF- $\alpha$ is an important cytokine that stimulates spermatogenesis and decreases aromatase activation from Sertoli cells (53). While TNF- $\alpha$ has a stimulating effect on 
aromatase and a positive effect on estradiol in pachytene spermatocytes, an inhibitory effect on round spermatid is observed (11). Cyclic AMP is an important regulator of aromatase gene transcription in somatic and germ cells in rat testis (11). In the molecular mechanisms here, the steroidogenic factor element response (SFRE) response is known as the extracellular regulator on aromatase, secondly the cyclic MAP response element (CRE), and the last as the TGF $\beta$ response element (54). External factors such as follicle-stimulating hormone (FSH), luteinizing hormone (LH), insulin-like growth factor-1 (IGF-1), and thyroid hormone (TH) affect the expression of aromatase in the testis (55-58). Steroidogenic factor-1 (SF-1) can regulate aromatase expression within the testis. It is found only in Leydig cells in adults (59). Liver receptor homolog-1 (LRH-1) and SF-1 play an important role in the regulation of aromatase expression by acting together with Leydig cells (60). It was revealed that the expression of leptin, adiponectin, and its receptors, as well as aromatase expression, increased significantly in Leydig cell tumors compared to the control. This suggests that in human Leydig cell tumors, lipid status, estrogen level, and signaling are interrelated (61). Thyroid hormone (TH) acts on aromatase. Especially in the studies, the effects of $\mathrm{TH}$ in masculinization or adding masculine features were mentioned. In studies conducted in fish, it has been observed that it stimulates Sertoli cell and spermatogonium proliferation in zebrafish, and inhibits estrogen receptor and CYP19A1 expression in adult male and female goldfish $(62,63)$.

\section{Conclusion}

Aromatase is found in Sertoli, Leydig cells, spermatogonium, spermatocyte, spermatid and spermatozoa. The role of estrogens in the male reproductive system has been shown to be important. It has been noted that it can lead to male infertility as a result of the lack of estrogen and estrogen receptors. Estrogens are notable in testicular function, fertility, and steroidogenesis in the male genital tract.

\section{Conflict of interests}

The authors declare no conflict of interests.

\section{Acknowledgement}

All researches contributed equally to the study.

\section{Reference}

1. Carreau S, Lambard S, Delalande C, et al. Aromatase expression and role of estrogens in male gonad : a review. Reproductive biology and endocrinology : RB\&E. 2003;1:35.

2. Levallet J, Bilinska B, Mittre $\mathrm{H}$, et al. Expression and Immunolocalization of Functional Cytochrome P450 Aromatase in Mature Rat Testicular Cells1. Biology of Reproduction. 1998;58(4):919-26.

3. Bulun SE, Takayama K, Suzuki T, et al. Organization of the human aromatase $\mathrm{p} 450$ (CYP19) gene. Seminars in reproductive medicine. 2004;22(1):5-9.

4. Bulun SE, Lin $\mathrm{ZH}$, Imir $\mathrm{G}$, et al. Regulation of aromatase expression in estrogenresponsive breast and uterine disease: From bench to treatment. Pharmacological Reviews. 2005;57(3):359-83.

5. Yildirım AB. The effects of maternal hypothyroidism on the immunoreactivity of cytochrome p450 aromatase in the postnatal rat testes. 2015; Doctoral thesis.

6. Papadopoulos V CS, Szerman-Joly E, Drosdowsky MA, et al. Rat testis $17 \beta$-estradiol: identification by gas chromatography-mass spectrometry and age related cellular distribution. J Steroid Biochem 1986;24:1211-6.

7. Lambard S, Silandre D, Delalande C, et al. Aromatase in testis: expression and role in male reproduction. The Journal of steroid biochemistry and molecular biology. 2005;95(1-5):63-9. 
8. Yildirim AB, Ozdamar S, Kaymak E. The effects of maternal hypothyroidism on the immunoreactivity of cytochrome p450 aromatase in the postnatal rat testicles. Acta endocrinologica (Bucharest, Romania : 2005). 2017;13(1):7-16.

9. Hess RA. Oestrogen in fluid transport in efferent ducts of the male reproductive tract. Reviews of reproduction. 2000;5(2):84-92.

10. Grumbach MM, Auchus RJ. Commentary - Estrogen consequences and implications of human mutations in synthesis and action. Journal of Clinical Endocrinology \& Metabolism. 1999;84(12):4677-94.

11. Bourguiba S, Chater S, Delalande C, et al. Regulation of aromatase gene expression in purified germ cells of adult male rats: effects of transforming growth factor beta, tumor necrosis factor alpha, and cyclic adenosine 3',5'monosphosphate. Biol Reprod. 2003;69(2):592601.

12. Bourguiba S, Lambard S, Carreau S. Steroids control the aromatase gene expression in purified germ cells from the adult male rat. Journal of molecular endocrinology. 2003;31(1):83-94.

13. Mitrunen K, Hirvonen A. Molecular epidemiology of sporadic breast cancer - The role of polymorphic genes involved in oestrogen biosynthesis and metabolism. Mutation ResearchReviews in Mutation Research. 2003;544(1):9-41.

14. Simpson ER, Davis SR. Minireview: Aromatase and the regulation of estrogen biosynthesis - Some new perspectives. Endocrinology. 2001;142(11):4589-94.

15. Simpson ER, Zhao Y, Agarwal VR, et al. Aromatase expression in health and disease. Recent Progress in Hormone Research, Proceedings of the 1996 Conference, Vol 52. 1997;52:185-214.

16. Saunders PT, Sharpe RM, Williams K, et al. Differential expression of oestrogen receptor alpha and beta proteins in the testes and male reproductive system of human and non-human primates. Molecular human reproduction. 2001;7(3):227-36.

17. Scobie GA, Macpherson S, Millar MR, et al. Human oestrogen receptors: differential expression of ER alpha and beta and the identification of ER beta variants. Steroids. 2002;67(12):985-92.

18. Chen Y, Bunick D, Bahr J, et al. Isolation and culture of epithelial cells from rat ductuli efferentes and initial segment epididymidis. Tissue and Cell. 1998;30(1):1-13.

19. Fisher J, Millar M, Majdic G, et al. Immunolocalisation of oestrogen receptor- $\alpha$ within the testis and excurrent ducts of the rat and marmoset monkey from perinatal life to adulthood. Journal of Endocrinology. 1997;153(3):485-95.

20. Hess RA, Gist DH, Bunick D, et al. Estrogen receptor ( $\alpha$ and $\beta$ ) expression in the excurrent ducts of the adult male rat reproductive tract. Journal of andrology. 1997;18(6):602-11.

21. O'donnell L, Robertson KM, Jones ME, et al. Estrogen and spermatogenesis. Endocrine reviews. 2001;22(3):289-318.

22. Bulun SE. Aromatase and estrogen receptor alpha deficiency. Fertility and sterility. 2014;101(2):323-9.

23. Deroo BJ, Korach KS. Estrogen receptors and human disease. The Journal of clinical investigation. 2006;116(3):561-70.

24. Smith EP, Boyd J, Frank GR, et al. Estrogen resistance caused by a mutation in the estrogen-receptor gene in a man. The New England journal of medicine. 1994;331(16):1056-61.

25. Carani C, Qin K, Simoni M, et al. Effect of testosterone and estradiol in a man with aromatase deficiency. The New England journal of medicine. 1997;337(2):91-5.

26. Morishima A, Grumbach MM, Simpson ER, et al. Aromatase deficiency in male and female siblings caused by a novel mutation and the physiological role of estrogens. The Journal of clinical endocrinology and metabolism. 1995;80(12):3689-98.

27. Grumbach MM. Aromatase deficiency and its consequences. Advances in experimental medicine and biology. 2011;707:19-22.

28. Zirilli L, Rochira V, Diazzi C, et al. Human models of aromatase deficiency. The Journal of steroid biochemistry and molecular biology. 2008;109(3-5):212-8.

29. Kotula-Balak M, Bablok L, Fracki S, et al. Immunoexpression of androgen receptors and aromatase in testes of patient with Klinefelter's syndrome. Folia histochemica et cytobiologica. 2004;42(4):215-20.

30. Li X, Nokkala E, Yan W, et al. Altered structure and function of reproductive organs in transgenic male mice overexpressing human aromatase. Endocrinology. 2001;142(6):2435-42.

31. Santen RJ, Brodie H, Simpson ER, et al. History of aromatase: saga of an important biological mediator and therapeutic target. Endocrine reviews. 2009;30(4):343-75.

32. Wit JM, Hero M, Nunez SB. Aromatase inhibitors in pediatrics. Nature Reviews Endocrinology. 2011;8(3):135-47.

33. Seifert-Klauss V, Rabe T, Krämer A, et al. Update on Aromatase Inhibitors. Journal für Reproduktionsmedizin und Endokrinologie-Journal of Reproductive Medicine and Endocrinology. 2016;12(4):353-9.

34. Miller WR, Dixon JM. Endocrine and clinical endpoints of exemestane as neoadjuvant therapy. Cancer control : journal of the Moffitt Cancer Center. 2002;9(2 Suppl):9-15.

35. Pavlovich CP, King P, Goldstein M, et al. Evidence of a treatable endocrinopathy in infertile men. The Journal of urology. 2001;165(3):837-41. 
36. Stephens SM, Polotsky AJ. Big enough for an aromatase inhibitor? How adiposity affects male fertility. Seminars in reproductive medicine. 2013;31(4):251-7.

37. Santen RJ. Feedback control of luteinizing hormone and follicle-stimulating hormone secretion by testosterone and estradiol in men: physiological and clinical implications. Clinical biochemistry. 1981;14(5):243-51.

38. Carreau S, Genissel C, Bilinska B, et al. Sources of oestrogen in the testis and reproductive tract of the male. International journal of andrology. 1999;22(4):211-23.

39. de Jong FH, Hey AH, van der Molen HJ. Effect of gonadotrophins on the secretion of oestradiol- and testosterone by the rat testis. The Journal of endocrinology. 1973;57(2):277-84.

40. Carreau S, Wolczynski S, Galeraud-Denis I. Aromatase, oestrogens and human male reproduction. Philosophical transactions of the Royal Society of London Series B, Biological sciences. 2010;365(1546):1571-9.

41. Brodie A, Inkster S. Aromatase in the human testis. The Journal of steroid biochemistry and molecular biology. 1993;44(4-6):549-55.

42. Matsumoto $\mathrm{T}$, Honda S, Harada N. Alteration in sex-specific behaviors in male mice lacking the aromatase gene. Neuroendocrinology. 2003;77(6):416-24.

43. Robertson KM, Simpson ER, LachamKaplan O, et al. Characterization of the fertility of male aromatase knockout mice. Journal of andrology. 2001;22(5):825-30.

44. Carani C, Rochira V, Faustini-Fustini M, et al. Role of oestrogen in male sexual behaviour: insights from the natural model of aromatase deficiency. Clinical endocrinology. 1999;51(4):517-24.

45. Herrmann BL, Saller B, Janssen OE, et al. Impact of estrogen replacement therapy in a male with congenital aromatase deficiency caused by a novel mutation in the CYP19 gene. The Journal of clinical endocrinology and metabolism. 2002;87(12):5476-84.

46. Maffei L, Murata Y, Rochira V, et al. Dysmetabolic syndrome in a man with a novel mutation of the aromatase gene: effects of testosterone, alendronate, and estradiol treatment. The Journal of clinical endocrinology and metabolism. 2004;89(1):61-70.

47. Brooks DC, Coon VJ, Ercan CM, et al. Brain Aromatase and the Regulation of Sexual Activity in Male Mice. Endocrinology. 2020;161(10).

48. Simpson ER, Mahendroo MS, Means GD, et al. Aromatase cytochrome P450, the enzyme responsible for estrogen biosynthesis. Endocrine reviews. 1994;15(3):342-55.

49. Corbin CJ, Graham-Lorence S, McPhaul $\mathrm{M}$, et al. Isolation of a full-length cDNA insert encoding human aromatase system cytochrome P450 and its expression in nonsteroidogenic cells. Proceedings of the National Academy of Sciences of the United States of America. 1988;85(23):894852.

50. Bois C, Delalande C, Nurmio $M$, et al. Age- and cell-related gene expression of aromatase and estrogen receptors in the rat testis. Journal of molecular endocrinology. 2010;45(3):147-59.

51. Carreau S, Delalande C, Silandre D, et al. Aromatase and estrogen receptors in male reproduction. Molecular and cellular endocrinology. 2006;246(1-2):65-8.

52. Silandre D, Delalande C, Durand P, et al. Three promoters PII, PI.f, and PI.tr direct the expression of aromatase (cyp19) gene in male rat germ cells. Journal of molecular endocrinology. 2007;39(2):169-81.

53. Simpson ER, Zhao Y. Estrogen biosynthesis in adipose. Significance in breast cancer development. Annals of the New York Academy of Sciences. 1996;784:18-26.

54. Haverfield JT, Ham S, Brown KA, et al. Teasing out the role of aromatase in the healthy and diseased testis. Spermatogenesis. 2011;1(3):240-9.

55. Dorrington JH, Armstrong DT. Folliclestimulating hormone stimulates estradiol-17beta synthesis in cultured Sertoli cells. Proceedings of the National Academy of Sciences of the United States of America. 1975;72(7):2677-81.

56. Valladares LE, Payne AH. Induction of testicular aromatization by luteinizing hormone in mature rats. Endocrinology. 1979;105(2):431-6.

57. Sirianni R, Chimento A, Malivindi R, et al. Insulin-like growth factor-I, regulating aromatase expression through steroidogenic factor 1, supports estrogen-dependent tumor Leydig cell proliferation. Cancer research. 2007;67(17):8368-77.

58. Catalano S, Pezzi V, Chimento A, et al. Triiodothyronine Decreases the Activity of the Proximal Promoter (PII) of the Aromatase Gene in the Mouse Sertoli Cell Line, TM4. Molecular Endocrinology. 2003;17(5):923-34.

59. Hatano O, Takayama K, Imai T, et al. Sexdependent expression of a transcription factor, Ad4BP, regulating steroidogenic P-450 genes in the gonads during prenatal and postnatal rat development. Development (Cambridge, England). 1994;120(10):2787-97.

60. Wang ZJ, Jeffs B, Ito M, et al. Aromatase (Cyp19) Expression is up-Regulated by Targeted Disruption of Dax1. Proceedings of the National Academy of Sciences of the United States of America. 2001;98(14):7988-93.

61. Duliban M, Gorowska-Wojtowicz E. Interstitial Leydig Cell Tumorigenesis-Leptin and Adiponectin Signaling in Relation to Aromatase Expression in the Human Testis. 2020;21(10).

62. Morais RD, Nóbrega RH, GómezGonzález NE, et al. Thyroid hormone stimulates the 
proliferation of Sertoli cells and single type A spermatogonia in adult zebrafish (Danio rerio) testis. Endocrinology. 2013;154(11):4365-76.
63. Nelson ER, Allan ER, Pang FY, et al. Thyroid hormone and reproduction: regulation of estrogen receptors in goldfish gonads. Molecular reproduction and development. 2010;77(9):784-94. 